\title{
Assessment of P-Delta Effect on High Rise Building with Outriggers and Belt Truss
}

\author{
S Soundarya ${ }^{1} \mid$ V Bhargavi ${ }^{2}$ | Y Priyanka ${ }^{3}$
}

${ }^{1}$ PG Scholar, Department of Civil Engineering, Visakha Technical Campus, Andhra Pradesh, India.

${ }^{2}$ Associate Professor, Department of Civil Engineering, Visakha Technical Campus, Andhra Pradesh, India.

${ }^{3}$ Assistant Professor, Department of Civil Engineering, Visakha Technical Campus, Andhra Pradesh, India.

\section{To Cite this Article}

S Soundarya, V Bhargavi and Y Priyanka, "Assessment of P-Delta Effect on High Rise Building with Outriggers and Belt Truss", International Journal for Modern Trends in Science and Technology, 6(8): 72-79, 2020.

\section{Article Info}

Received on 16-June-2020, Revised on 05-July-2020, Accepted on 26-July-2020, Published on 02-August-2020.

\section{ABSTRACT}

The behaviour of structures, when subjected to critical loads is a complex phenomenon and is basically dependent on the type of forces/loads acting on the structure, magnitude of force, direction etc. Generally, the analysis of buildings is done by using linear elastic methods, which is first order structural analysis. The first order analysis is performed by assuming small deflection behaviour where the resulting forces, moments and displacements take no account of the additional effect due to deformation of the structure under vertical loads prior to imposing lateral loads. In the traditional first order analysis of structures, the effects of change in the structure actions due to structure deformations are neglected. However, when a structure deforms, the applied loads may cause additional actions in the structure that are called second order or p-delta effects. $P$-delta effect is secondary effect on structure. It is also known as 'Geometric nonlinearity effect'. As number of storey's increases, $P$-delta effect becomes more important. In this study the P-delta effect on skyscraper is studied. Linear static analysis (without P-delta effect) and nonlinear static analysis (with P-delta effect) on high rise buildings having outrigger with belt truss is carried out. For the analysis G+55 composite skyscraper is modelled. Earthquake load is applied on model of structure as per IS-1893(2002) for zone II in ETABS software. Load combinations for analysis are set as per IS-456(2000). Bending moment of column, story displacement with and without P-delta effect is calculated and compared for both models.

KEYWORDS: Nonlinear analysis, ETABS, P-Delta effect, High-Rise Building.

\section{INTRODUCTION}

Construction of high-rise buildings evolved feasible with the invention of the elevator and more sufficient construction materials with less cost. Construction of high-rise structures has technological and financial benefits in regions of high population density.

\section{Historically Background of High-Rise Building: -}

- The E. V. Haughwout Building in Manhattan is the world's first skyscraper due to it was the first building to install successfully a passenger elevator, in 1857.

- Later in 1930 the Chrysler Building took the lead as the tallest building in the world, scraping the sky at 1,046 feet $(319 \mathrm{~m})$ which is designed by William Van Alen. It is an Art Deco style masterpiece with an exterior crafted of brick.

- In 1931 "The Empire State Building", with a height of 1,250 feet $(381 \mathrm{~m})$, it took the top spot as tallest building, and towered above all other 
buildings until 1972. And also, it is the first building to have more than 100 floors it has 102 . It structure is designed by Shreve, Lamb and Harmon in the modern Art Deco manner. The building grabs its caption from the sobriquet of New York State. The antenna pole augmented in 1951 gave rise to crown height to 1,472 feet (449 $\mathrm{m})$, reduced in 1984 to 1,454 feet $(443 \mathrm{~m})$.

- The Sears Tower was finished in 1974, one year after the World Trade Center, and defeated it as the world's tallest structure. It is the first structure-to utilize the "bundled tube" structural system, which is designed by Fazlur Khan. The structure was not exceeded in height until the Petronas Towers were built in 1998, but persisted the tallest in some districts until Burj Khalifa overtook in all aspects in 2010 .

\section{Outrigger System: -}

The outrigger system is an efficient structural form in order to resist the lateral loads acting on the structure. In which the central core of the building and perimeter columns of the building are connected with outriggers. Generally, the central core building is constructed either shear walls or braced frames. the lateral loads acting on the building vertical plane which creates rotations in structure which are resisted by the outriggers through compression in the leeward columns and tension in the windward columns. Due to providing of outriggers join the columns and makes structure behave approximately as act as single cantilever member. Even though the exterior columns, which are not directly attached to the outriggers, but it reduces the lateral deformation of structure by connecting all the exterior columns with a horizontal girder around the structure facade.

\section{The Concept of Outrigger: -}

The concept of outrigger is inspired from the great sailing ships of the past and present use outriggers to help resist the wind forces in their sails. Let us assume Like the ship, the central core of the structure can be similar to the mast of the ship, and the outrigger acting as the spreaders and the perimeter columns as stays or shroud of the ship.

\section{Types of Outrigger Truss System: -}

Based on the connection between the core to exterior columns, this outrigger system is divided into two categories:

\section{- Conventional Outrigger Concept}

\section{- Virtual Outrigger Concept Conventional Outrigger Concept: -}

In which the outrigger girders or trusses are connected directly to braced frames or shear walls at the central core and to columns located outboard of the core. Typically, the columns are at the outer edges of the building.

\section{Virtual Outrigger Concept: -}

Similarly, to the conventional outrigger systems, the outriggers are transfer of overturning from the central core to external columns of the building is achieved, but without a direct connection between the outrigger trusses and the central core of the building. The fundamental idea behind the virtual outrigger concept is to use floor diaphragms, because they are typically very stiff and strong in their own plane.

\section{Belt Trusses as Virtual Outriggers: -}

If we use belt trusses as virtual outriggers which avoids many of the problems associated with the use of conventional outriggers. The morality is the identical as when belt trusses are utilized as virtual outriggers. But in which some percentage of the moment in the core is transformed into a horizontal couple in the floors at the top and the bottom of the basement.

\section{Analysis of Tall buildings :-}

The P- $\Delta$ or P-Delta impact refers to the sudden differences in ground shear, overturning moment, and the axial force distribution at the base of an adequately tall structure or structural element when it is accountable to a crucial lateral displacement. A significance can be made between P-Delta effects on a multi-level structure, written as P- $\Delta$, and the effects on components deflecting within a level, written as P- $\delta$.

P-delta effect is also known as 'Geometric nonlinearity effect' since their magnitude relies on the quantity of preliminary displacement or deflection. The P-delta effect is a destabilizing moment equal to the product of axial force and lateral displacement of the structure that tolerates when substantial laterally. If a P-Delta affected component is subjected to lateral load, therefore it will be possible to deflect more which could be evaluated by P-Delta study and not by the linear static assessment. This consequence may decrease considerably increase the flexural capability of a structure. To illustrate this, let us assume the simple cantilevered column model as shown below: 


\section{P-Delta Effect}

In this illustration, a column of length $\mathrm{L}$ is experiencing an axial force $(\mathrm{P})$ and a lateral force (V). In linear

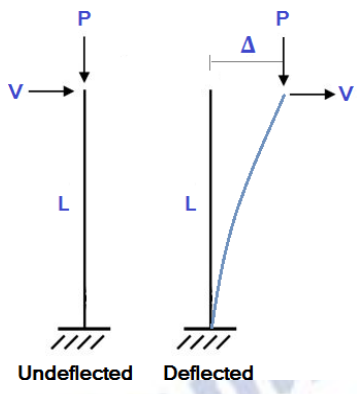

- To know how to analyse tall building with and

- To determine P-delta analysis influence on the static analysis, we will evaluate the lateral deflection $(\Delta)$ as:

$\Delta=\mathrm{ML}^{2} / 3 \mathrm{EI}=\mathrm{VL}^{3} / 3 \mathrm{EI}$ since $\mathrm{M}=\mathrm{VL}$

To exemplify this, let's take total the moments about the base of the column:

$\sum \mathrm{M}=(\mathrm{V} \times \mathrm{L})+(\mathrm{P} \times \Delta)=\mathrm{VL}+\mathrm{P} \Delta \mathrm{M} 1=\mathrm{VL}$

$\mathrm{M} 2=\mathrm{P} \Delta$

Nonetheless, where M1 is due to the lateral load and, M2 is due to the axial force. Each of the moments contributes to lateral deflection differently:

\section{$\Delta 1=\mathrm{M}_{1} \mathrm{~L}^{2} / 3 \mathrm{EI}=\mathrm{VL}^{3} / 3 \mathrm{EI}$}

$\Delta 2=\mathrm{M}_{2} \mathrm{~L}^{2} / 2 \mathrm{EI}=\mathrm{P} \Delta \mathrm{L}^{2} / 2 \mathrm{EI}$

So actually, the cumulative lateral deflection would be near to:

$\Delta$ new $=\Delta 1+\Delta 2=\mathrm{VL}^{3} / 2 \mathrm{EI}$

We can observe that correlated to the actual deflection magnitude, there is an additional term on the right in terms of $\mathrm{P}$ and $\Delta$. If $\mathrm{P}$ or $\Delta$ are considerable magnitude's, the linear static analysis would be miscalculating the deflection of the column. It should be evident now that a P-Delta Analysis is designated after the secondary moment $\mathrm{P} \Delta$. An adequate P-Delta Analysis would persist to iterate the procedure above to renovate the value of $\Delta$ new. This consequence will evolve significant exclusively if this outcome is extensively huge. The Magnitude of P- Delta Effect depends on:

- Extent of axial load.

- Stiffness/slenderness of the entire structure.

- Slenderness of individual component's

As per Technical Standard of Building, National Building Code, Earthquake-Resistant Design ', clause 4.1.5, page 19: The second order effects without P-Delta analysis by using ETABS. variation of responses of the structure such as bending moments, displacements, axial force and story stiffness when compared to linear static analysis.

To study the effect of outriggers and belt truss

must be considered when an increase of more than $10 \%$ occurs in internal forces.

\section{Motives of the current study: -}

system on the parameters bending moments, displacements, axial force and story stiffness.

\section{METHODOLOGY}

\section{Study of Previous Studies:}

Keeping the important points of the previous studies in mind, in this project 6 models $(G+55)$ tall structure is analysed for various cases in seismic zone II and compared the results (such as with and without P-Delta effect) and studied storey displacement, storey stiffness, axial forces, and column bending moments obtained from the analysis. And chosen ETABS Software for analysing the structure as per Indian standards.

\section{Modelling of the structure: -}

In order to observe the P-Delta effect on the structure, both the geometry of the building and the actions and support conditions are idealised by compromises of a sufficient mathematical model, which must be likewise approximately indicate the stiffness circumstances of the cross-sections, components, connections and interaction with the surface. The entire modelling of all cases are done by using ETABS software.

\section{Computation of loads: -}

\section{Dead loads: -}

The lasting or inactive loads that are transmitted to the structure throughout their design period are known as Dead loads. These loads should be computed by calculating the amount of each construction material and then multiplying it with the unit weight of that Constitution material. The unit weights of various construction materials used in civil engineering constructions are provided in the Code IS 875(PART-1)-1987.

\section{Live loads: -}

These are the loads which are changes with respect to the time on the structure. These loads mainly 
due to the people occupying on the floor, the load of the movable walls, load furniture, and etc. As per Indian standards the live loads to be obtained for the design of structures have been given in IS: (875 PART-2)-1987.

\section{Wind loads acting on the structure: -}

Due to Wind load there three various kinds of consequences on structures which are static, dynamic and aerodynamic interference impacts in tall structures. The concept of wind load is detailed given in IS 875 released in 1964 considering wind consequences have been completely modified in the code publicized in 1987.

Design Wind Speed: -The design wind speed for a location is achieved from the fundamental wind speed at the location by utilizing the following formula:

$\mathrm{Vz}=\mathrm{Vb} \mathrm{k} 1 \mathrm{k} 2 \mathrm{k} 3$

Where,

$\mathrm{V}_{\mathrm{Z}}=$ Design wind speed (in $\mathrm{m} / \mathrm{s}$ ) at height, $\mathrm{Vb}=$ Basic wind speed for the site, $\mathrm{k} 1$ = Probability factor or risk coefficient with return period, $\mathrm{k} 2=$ Factor for the combined effects of terrain height and size of the component on structure, $k 3=$ Factor for local topography (hills, valleys, clith, etc.).

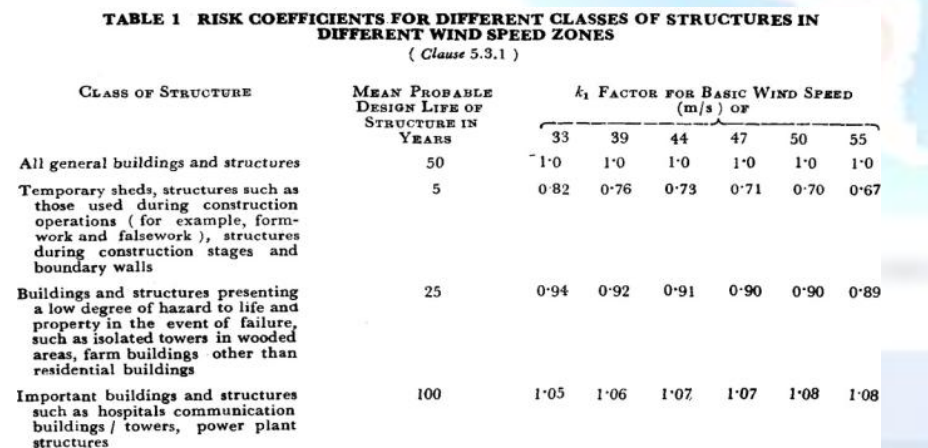

\section{Risk coefficient $\mathbf{k} 1$}

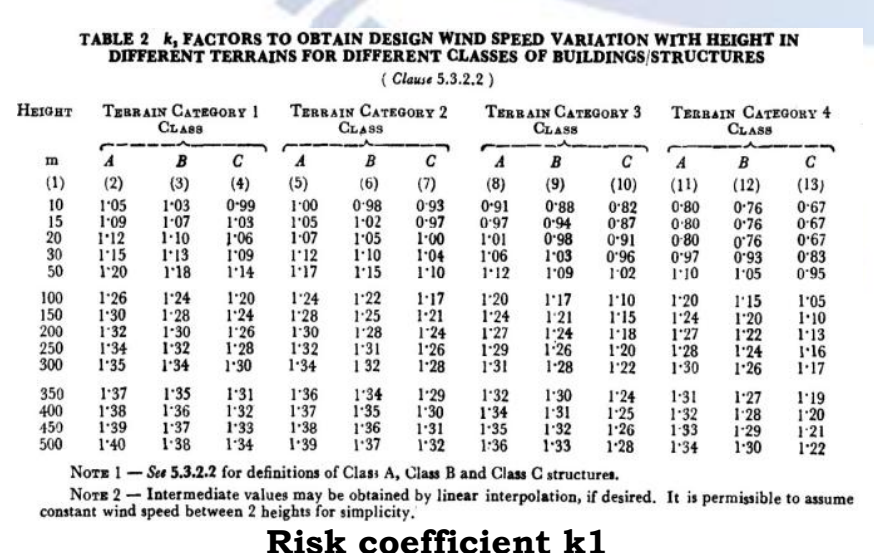

The value of $\mathrm{k} 2$, which assesses all the several factors like elevation, terrain classification and class of the structure are given in IS 875 Part3 (1987).

5.3.3.1 The effect of topography will be significart at a site when the upwind slope $(\theta)$ is greater than about $3^{\circ}$, and below that, the value of $k_{3}$ may be taken to be equal to $1 \cdot 0$. The value of $k_{3}$ is confined in the range of 1.0 to 1.36 for slopes greater than $3^{\circ}$. A method of evaluating the value of $k_{3}$ for values greater than 1.0 is given in Appendix C. It may be noted that the value of $k_{3}$ varies with height above ground level, at a maximum near the ground, and reducing to 1.0 at higher levels.

\section{Topography factor $\mathbf{k} 3$}

Seismic load calculation: The Indian standard regulations are: 1893-1984 and are: 13920-1993 possess stipulated the minimum design regulations of seismic-resistant design proportion of circumstance of seismic effects, the properties of the structure and the foundation and the adequate extent of damage

\section{Load combinations:}

Table 18 Values of Partial Safety Factor $\gamma_{f}$ for Loads (Clauses 18.2.3.1, 36.4.1 and B-4.3)

\begin{tabular}{|c|c|c|c|c|c|c|}
\hline \multirow[t]{2}{*}{ Load Combination } & \multicolumn{3}{|c|}{ Umit State of Collapse } & \multicolumn{3}{|c|}{$\begin{array}{l}\text { Limit States of } \\
\text { Serviceabillity }\end{array}$} \\
\hline & $D L$ & $\pi$ & WL & $D L$ & IL & $W L$ \\
\hline (1) & (2) & (3) & (4) & (5) & (6) & (7) \\
\hline$D L+I L$ & \multicolumn{2}{|c|}{1.5} & 1.0 & 1.0 & 1.0 & - \\
\hline$D L+W L$ & \multicolumn{3}{|l|}{0,911} & 1.0 & - & 1.0 \\
\hline$D L+I L+W L$ & \multicolumn{6}{|c|}{ NOTES } \\
\hline \multicolumn{7}{|c|}{$\begin{array}{l}2 \text { For the limit states of serviceability, the values of } \gamma_{\text {, given in this table are applicable for short temn effects. While assessing the }} \text { long term effects due to creep the dead load and that part of the live load likely to be permanent may only be considered. }\end{array}$} \\
\hline
\end{tabular}

\section{ANALYIS OF THE STRUCTURE BY USING} ETABS

Primary Data: -

Details for Building Models

\begin{tabular}{|c|c|}
\hline \multicolumn{2}{|l|}{ Details for Building Models } \\
\hline Plan Size & $37.8 \mathrm{~m} \times 47.7 \mathrm{~m}$ \\
\hline No. of Floors & $\mathrm{G}+55$ \\
\hline Storey Height & $168.5 \mathrm{~m}$ \\
\hline Type of soil & II \\
\hline Grade of Concrete & M30 \\
\hline Grade of Steel & Fe500 \\
\hline Column Size & $450 \mathrm{~mm} \times 450 \mathrm{~mm}$ \\
\hline Slab Thickness & $150 \mathrm{~mm}$ \\
\hline Zone & II \\
\hline Live Load & $3 \mathrm{kN} / \mathrm{m}^{2}$ \\
\hline Floor Finish Load & $1.5 \mathrm{kN} / \mathrm{m}^{2}$ \\
\hline Earthquake Load & $\begin{array}{l}\text { As Per } \\
\text { IS: } 1893(\text { Part-I)-2002 }\end{array}$ \\
\hline
\end{tabular}




\begin{tabular}{|l|l|}
\hline Zone Factor & 0.10 \\
\hline Response Reduction Factor & 5 \\
\hline Wind Load & As Per IS: \\
& $875: 1987$ (Part-3) \\
\hline Wind Speed & $50 \mathrm{~m} / \mathrm{s}$ \\
\hline Terrain Category & 3 \\
\hline Structure Class & $\mathrm{C}$ \\
\hline
\end{tabular}

\section{P-Delta Analysis and Results of Tall Building by} Using ETABS: -

The step by step procedure for P-Delta analysis is given in follow:

1) First, we select new model option in the software. And then we need to select the codes.

2) After the selection of default settings then we need to define grid in the ETABS software. Then define length and width of bays and number of bays in $\mathrm{X}$ and $\mathrm{Y}$ direction and number of Story and storey height and then base storey height.

3) After defining the grid, then select the flat slab grid model. Then we need to define the material properties.

4) After defining material properties, then we need to define the sectional properties like column and slab.

5) After selection of sectional properties, then draw the structural plan of the structure.

Similarly, the modelling of buildings for remaining cases is also done by same procedure but with addition of outriggers and belt truss systems
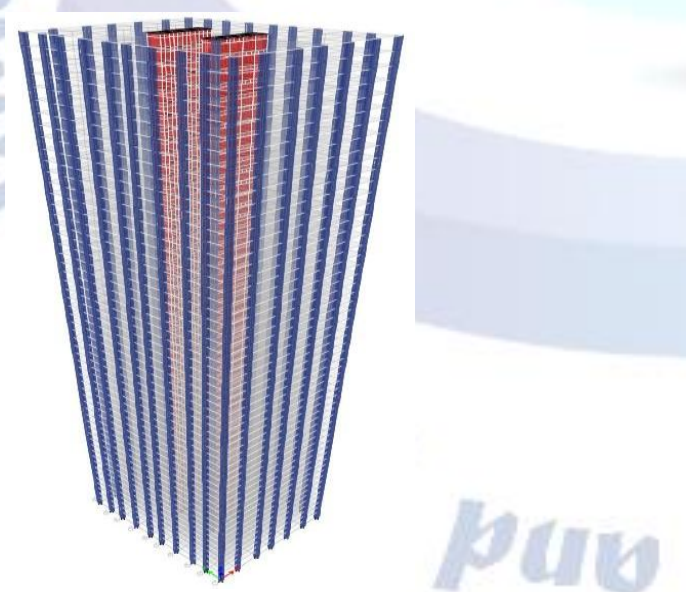

3D View of the Structure

\section{RESULTS AND DISCUSSION}

Storey Displacement(mm):-Case 1: The displacement of the structure for various combination of loads for model 1 and model 2 and also the percentage of difference between are presented in table 4.1 and graph shown in figure 4.1 with shows the variation of displacement with and without P-Delta effect for model 1 and model 2 .

Displacement of $(G+55)$ tall building with and without P-Delta effect

\begin{tabular}{|l|l|l|l}
\hline \multirow{2}{*}{ Load combination } & \multicolumn{2}{|l|}{ Displacement (mm) } & \multirow{2}{*}{ \% of Difference } \\
\cline { 2 - 3 } & Without P-Delta & With P-Delta & \\
\hline $1.5(\mathrm{DL}+\mathrm{LL})$ & 34.6 & 36.97 & 6.849710983 \\
\hline $1.2(\mathrm{DL}+\mathrm{LL}+\mathrm{WY}+)$ & 1042 & 1121.46 & 7.62571977 \\
\hline $1.2(\mathrm{DL}+\mathrm{LL}+\mathrm{WY}-)$ & 1053.7 & 1134.11 & 7.631204328 \\
\hline $1.2(\mathrm{DL}+\mathrm{LL}+\mathrm{WX}+)$ & 1061.5 & 1088.99 & 2.589731512 \\
\hline $1.2(\mathrm{DL}+\mathrm{LL}+\mathrm{WX}-)$ & 1039.23 & 1063.58 & 2.343080935 \\
\hline $1.2(\mathrm{DL}+\mathrm{LL}+\mathrm{EQY}+)$ & 28.2 & 31.14 & 10.42553191 \\
\hline $1.2(\mathrm{DL}+\mathrm{LL}+\mathrm{EQY}-)$ & 27.4 & 30.24 & 10.3649635 \\
\hline $1.2(\mathrm{DL}+\mathrm{LL}+\mathrm{EQX}+)$ & 155.6 & 174.05 & 11.85732648 \\
\hline $1.2(\mathrm{DL}+\mathrm{LL}+\mathrm{EQX}-)$ & 154.4 & 172.38 & 11.64507772 \\
\hline $0.9 \mathrm{DL}+1.5 \mathrm{WY}+$ & 1328.1 & 1547.66 & 16.53188766 \\
\hline $0.9 \mathrm{DL}+1.5 \mathrm{WY}-$ & 1301.16 & 1489.87 & 14.50321252 \\
\hline $0.9 \mathrm{DL}+1.5 \mathrm{WX}+$ & 1295.5 & 1476.32 & 13.95754535 \\
\hline $0.9 \mathrm{DL}+1.5 \mathrm{WX}-$ & 1287.56 & 1477.19 & 14.72785734 \\
\hline $0.9 \mathrm{DL}+1.5 \mathrm{EQY}+$ & 9.8 & 10.2 & 4.081632653 \\
\hline $0.9 \mathrm{DL}+1.5 \mathrm{EQX}+$ & 220 & 249 & 13.18181818 \\
\hline
\end{tabular}




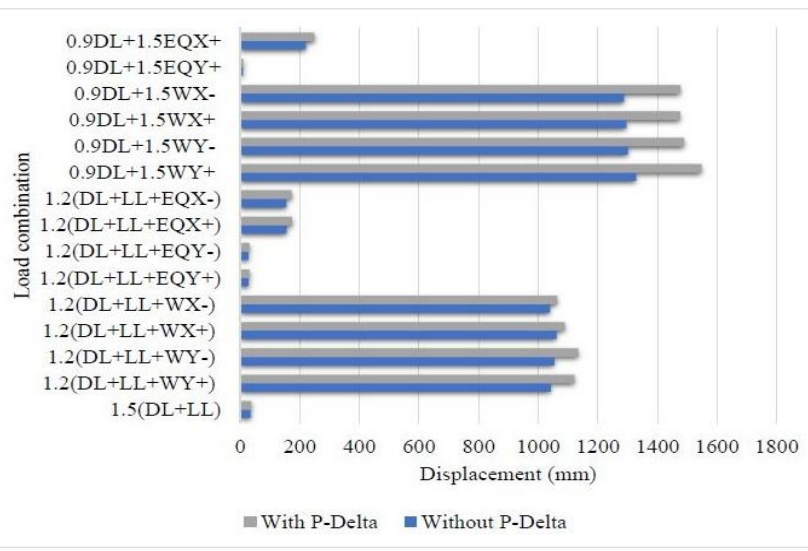

Case 2:The displacement of the structure for various combination of loads for model 5 and model6 and also the percentage of difference between are presented in table 4.2 and graph shown in figure 4.2 with shows the variation of displacement with and without P-Delta effect for mode15 and model6.

\section{Displacement of $(G+55)$ Tall Building with Outrigger and Belt Truss with and without P-Delta Effect}

\begin{tabular}{|c|c|c|c|}
\hline \multirow{2}{*}{ Load combination } & \multicolumn{2}{|c|}{ Displacement (mm) } & \multirow{2}{*}{ \% of Difference } \\
\cline { 2 - 3 } & Without P-Delta & With P-Delta & \\
\hline $1.5(\mathrm{DL}+\mathrm{LL})$ & 24.6 & 25.28 & 2.764227642 \\
\hline $1.2(\mathrm{DL}+\mathrm{LL}+\mathrm{WY}+)$ & 726.8 & 769.01 & 5.807649972 \\
\hline $1.2(\mathrm{DL}+\mathrm{LL}+\mathrm{WY}-)$ & 734.55 & 781.81 & 6.433871078 \\
\hline $1.2(\mathrm{DL}+\mathrm{LL}+\mathrm{WX}+)$ & 740.08 & 756.14 & 2.170035672 \\
\hline $1.2(\mathrm{DL}+\mathrm{LL}+\mathrm{WX}-)$ & 704.63 & 719.33 & 2.086201269 \\
\hline $1.2(\mathrm{DL}+\mathrm{LL}+\mathrm{EQY}+)$ & 20.3 & 22.05 & 8.620689655 \\
\hline $1.2(\mathrm{DL}+\mathrm{LL}+\mathrm{EQY}-)$ & 19.7 & 21.4 & 8.629441624 \\
\hline $1.2(\mathrm{DL}+\mathrm{LL}+\mathrm{EQX}+)$ & 108.1 & 116.9 & 8.140610546 \\
\hline $1.2(\mathrm{DL}+\mathrm{LL}+\mathrm{EQX}-)$ & 107.3 & 119.59 & 11.45386766 \\
\hline $0.9 \mathrm{DL}+1.5 \mathrm{WY}+$ & 926.6 & 1041.93 & 12.44657889 \\
\hline $0.9 \mathrm{DL}+1.5 \mathrm{WY}-$ & 910.41 & 1017.06 & 11.71450226 \\
\hline $0.9 \mathrm{DL}+1.5 \mathrm{WX}+$ & 894.98 & 995.4 & 11.22036247 \\
\hline $0.9 \mathrm{DL}+1.5 \mathrm{WX}-$ & 873.12 & 994.42 & 13.89270662 \\
\hline $0.9 \mathrm{DL}+1.5 \mathrm{EQY}+$ & 7.2 & 7.47 & 3.75 \\
\hline $0.9 \mathrm{DL}+1.5 \mathrm{EQX}+$ & 153.2 & 171.46 & 11.91906005 \\
\hline
\end{tabular}

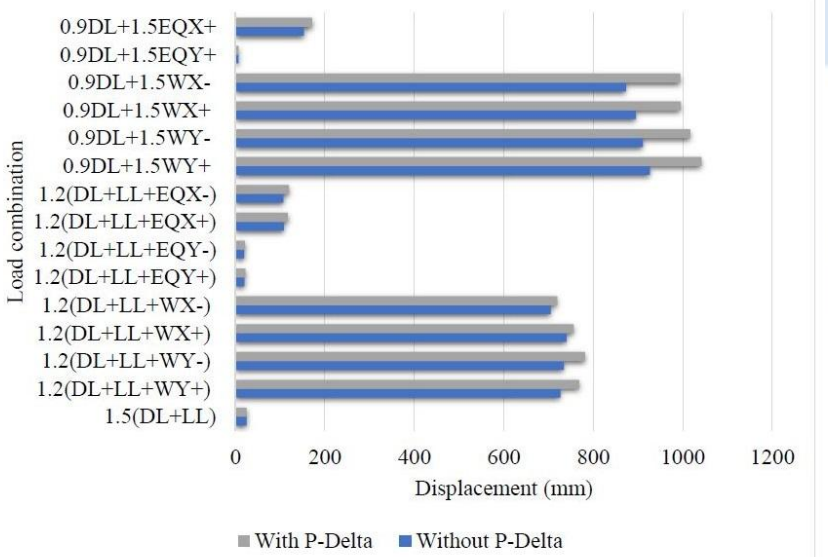

various combination of loads for model 1 and model2 and also the percentage of difference between are presented in table 4.3 and graph shown in figure 4.3 with shows the variation of stiffness with and without P-Delta effect for model 1 and model2.

Stiffness Of $(G+55)$ Tall Building with and without P-Delta Effect

\begin{tabular}{|c|c|c|c|}
\hline \multirow{2}{*}{$\begin{array}{l}\text { Story } \\
\text { number }\end{array}$} & \multicolumn{2}{|c|}{ Stiffness } & $\begin{array}{l}\text { \% } \\
\text { of } \\
\text { Difference }\end{array}$ \\
\cline { 2 - 4 } & $\begin{array}{c}\text { without } \\
\text { P-Delta }\end{array}$ & with P-Delta & \\
\hline Story56 & 23750.427 & 16350.003 & 31.1591 \\
\hline Story50 & 173493.966 & 123304.129 & 28.9289 \\
\hline Story43 & 309152.242 & 224609.67 & 27.3466 \\
\hline Story36 & 419706.074 & 310729.756 & 25.9649 \\
\hline Story29 & 526952.458 & 394723.516 & 25.0931 \\
\hline Story22 & 662323.62 & 495899.922 & 25.1272 \\
\hline Story15 & 896557.884 & 658082.236 & 26.599 \\
\hline Story8 & 1524056.282 & 1066071.325 & 30.0504 \\
\hline Story1 & 11259737 & 7898098.496 & 29.8554 \\
\hline
\end{tabular}

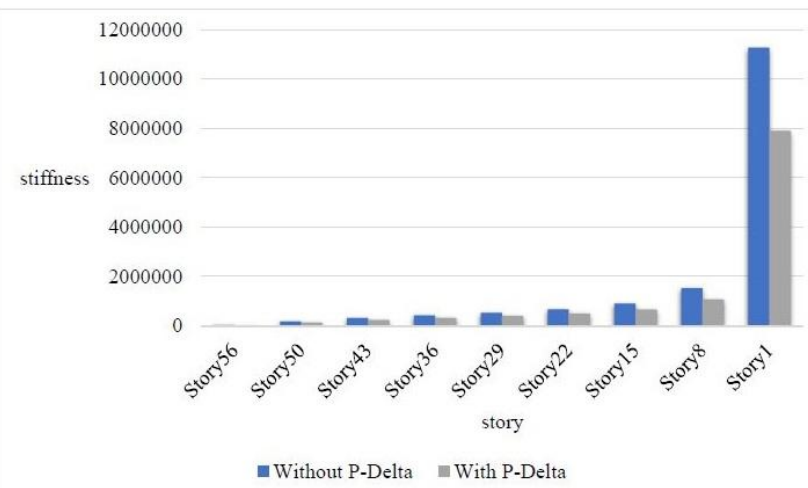

\section{Stiffness Of $(G+55)$ with Outrigger with and without P-Delta Effect}

Case2:The stiffness of the structure for various combination of loads for model 3 and model 4 and also the percentage of difference between are presented in table 4.4 and graph shown in figure 4.4. with shows the variation of stiffness with and without P-Delta effect for model3 and model4.

\begin{tabular}{|c|c|c|c|}
\hline \multirow{2}{*}{$\begin{array}{l}\text { Story } \\
\text { number }\end{array}$} & \multicolumn{2}{|c|}{ Stiffness } & \multirow{2}{*}{$\begin{array}{lr}\% & \text { of } \\
\text { Difference }\end{array}$} \\
\hline & $\begin{array}{l}\text { without } \\
\text { P-Delta }\end{array}$ & with P-Delta & \\
\hline Story56 & 31950.52 & 23750.427 & 25.665 \\
\hline Story50 & 237119.577 & 173493.96 & 26.8327 \\
\hline Story 43 & 433637.38 & 309152.24 & 28.7072 \\
\hline Story36 & 553873.002 & 419706.07 & 24.2234 \\
\hline Story29 & 725898.625 & 526952.45 & 27.4069 \\
\hline Story22 & 847796.359 & 662323.62 & 21.877 \\
\hline Story 15 & 1168823.782 & 896557.88 & 23.294 \\
\hline Story8 & 1813443.732 & 1324056.28 & 15.9579 \\
\hline Story 1 & 12216635 & 11259737.1 & 7.83275 \\
\hline
\end{tabular}

\section{Stiffness:-}

Case1:The stiffness of the structure for 


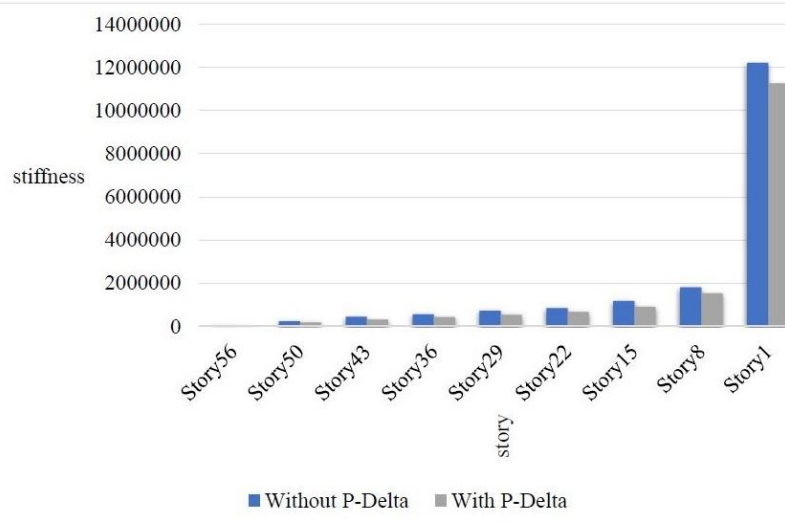

\section{Bending moment:}

The Bending moment of the structure for various combination of loads for model 1 and model 2 and also the percentage of difference between are presented in table 4.5 .

\section{Bending moment of $(\mathrm{G}+55)$ tall building with and without P-Delta effect}

\begin{tabular}{|c|c|c|c|}
\hline \multirow{2}{*}{ Load combination } & \multicolumn{2}{|c|}{$\begin{array}{c}\text { Bending Moment } \\
(\mathbf{k N}-\mathbf{m})\end{array}$} & \multirow[t]{2}{*}{$\begin{array}{ll}\% & \text { of } \\
\text { Difference }\end{array}$} \\
\hline & $\begin{array}{l}\text { without } \\
\text { P-Delta }\end{array}$ & $\begin{array}{c}\text { with } \\
\text { P-Delta }\end{array}$ & \\
\hline $1.5(\mathrm{DL}+\mathrm{LL})$ & 224.31 & 238.43 & 6.294859792 \\
\hline 1.2(DL+LL+WY+) & 408.47 & 414.65 & 1.512963008 \\
\hline 1.2(DL+LL+WY-) & 365.88 & 384.7 & 5.143762982 \\
\hline $1.2(\mathrm{DL}+\mathrm{LL}+\mathrm{WX}+)$ & 331.92 & 340.98 & 2.729573391 \\
\hline 1.2(DL+LL+WX-) & 310.11 & 321.87 & 3.792202767 \\
\hline 1.2(DL+LL+EQY+) & 204.75 & 207.01 & 1.103785104 \\
\hline 1.2(DL+LL+EQY-) & 195.05 & 198.34 & 1.686746988 \\
\hline 1.2(DL+LL+EQX+) & 249 & 263.89 & 5.979919679 \\
\hline 1.2(DL+LL+EQX-) & 263.78 & 281.66 & 6.778375919 \\
\hline $0.9 \mathrm{DL}+1.5 \mathrm{WY}+$ & 725.42 & 784.34 & 8.122191282 \\
\hline $0.9 \mathrm{DL}+1.5 \mathrm{WY}-$ & 706.31 & 722.12 & 2.238393906 \\
\hline $0.9 \mathrm{DL}+1.5 \mathrm{WX}+$ & 711.86 & 736.98 & 3.52878375 \\
\hline $0.9 \mathrm{DL}+1.5 \mathrm{WX}-$ & 698.14 & 715.61 & 2.502363423 \\
\hline 0.9DL+1.5EQY+ & 192.37 & 198.45 & 3.160575973 \\
\hline 0.9DL+1.5EQX+ & 287.09 & 298.1 & 3.83503431 \\
\hline
\end{tabular}

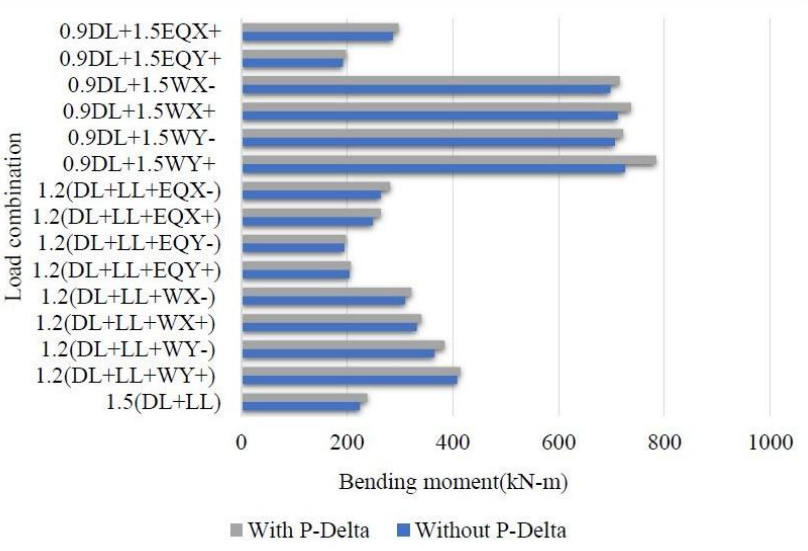

\section{Bending Moment of Column with and without P-Delta Effects}

Case 2: The Bending moment of the structure for various combination of loads for model 3 and model4 and also the percentage of difference between are presented in table 4.6.

\section{Bending Moment of $(\mathbf{G}+55)$ with Outrigger with and without P-Delta Effect}

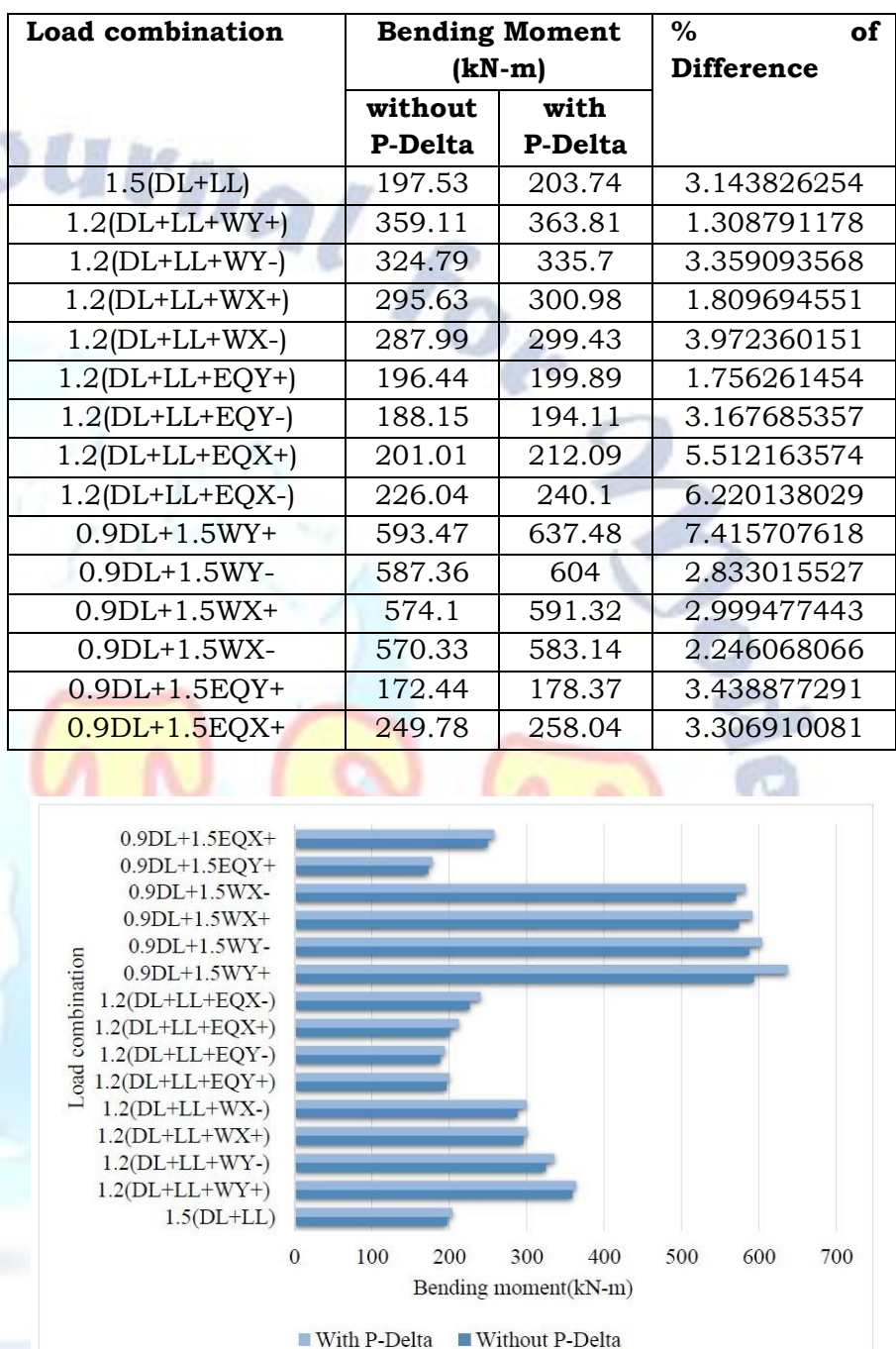

\section{v. CONCLUSION}

- From the results we conclude that, before designing the any structure it is necessary to check the P-delta analysis is required are not especially for tall buildings. And also, it shows that the P-delta effects have more effect in designing of a structure rather than first order effects.

- Displacements, bending moments with respect to wind load with P-delta effect is higher when compared with earthquake load with P-delta effect.

- The storey displacements, bending moments reduces and stiffness increases with increasing lateral resistance by providing outrigger and belt trusses. 
- Bending moment in column at ground floor is increases after the P-delta analysis.

- The result obtained that axial force increases with addition of outriggers and belt trusses.

- The effect of P-Delta effects on structure is decreases by using outriggers.

- And building with outriggers and belt truss are more effective when compared with building with outriggers.

\section{REFERENCES}

[1] Assessment Of P-Delta Effect on High Rise Buildings by Prashant Dhadve1,Alok Rao Volume:3 Issue 5, 2015.

[2] Study Of P-Delta Effect On Tall Steel Structure by Neeraj Kulkarni, S.M. Maheswerappa Volume:2, Issue 4, 2015

[3] Study of Structural Irregularities In High Rise Buildings With Po Effect by V.Guruprasad1, Arunkumar.B. Volume 5, Issue 9, Sep 2016.

[4] Behavior Of P-Delta Effect In High- Rise Buildings With And Without Shear Wall by Phanikumar.V, Deepthi, Saikiran K, R.B.N. Santhosh Volume 8, Issue 2, July 2019

[5] P-Delta Analysis Of Multi Story Rc Building by Rajath R T1, M Ramegowda Volume 5, Issue 12, Dec 2016.

[6] P-Delta Effect On High Rise Building Subjected To Earth Quake And Wind Load by Rizwan Akhter1, Shree Prakash2, Mirza Aamir Baig Volume 7, Issue 8, Aug 2017.

[7] Analysis Of P-Delta Effect On Multistory R.C. Building Without And with Shear Wall by Neelapu Ramesh Volume 4, Issue 2, Aug 2017.

[8] Analysis Of P-Delta Effect On High Rise Buildings by Pushparaj J. Dhawale [1] Prof. G. N. Narule [2] Volume 4, Issue 4, July-Aug 2016.

[9] Effects Of P-Delta On High Rise Buildings Located In Seismic Zones by Vijayalakshmi R, Bindu N Byadgi, Vahini M Volume 115, Issue 4, April 1989.

[10] Analysis Of P-Delta Effect on High Rise Building b y Yash Jobanputra, Alka Tomar, Volume 4, Issue5, May 2018.Effect Of P-Delta Action On Multi-Storey Buildings Prof. C. G. Konapure Volume 4, Issue 1, January 2015.

[11] P-Delta Effects On Tall Rc Buildings With And Without Shear Wall Rajat Sharma1, Raghvendra Singh2 Volume 4, Issue 11, November 2017.

[12] P-Delta Effects On Tall Rc Buildings With And Without Shear Wall Rajat Sharma1, Raghvendra Singh2 Volume 4, Issue 11, November 2017.

[13] Effect Of P-Delta Action On Multi-Storey Buildings Prof. C. G. Konapure Volume 4, Issue 1, January 2015.
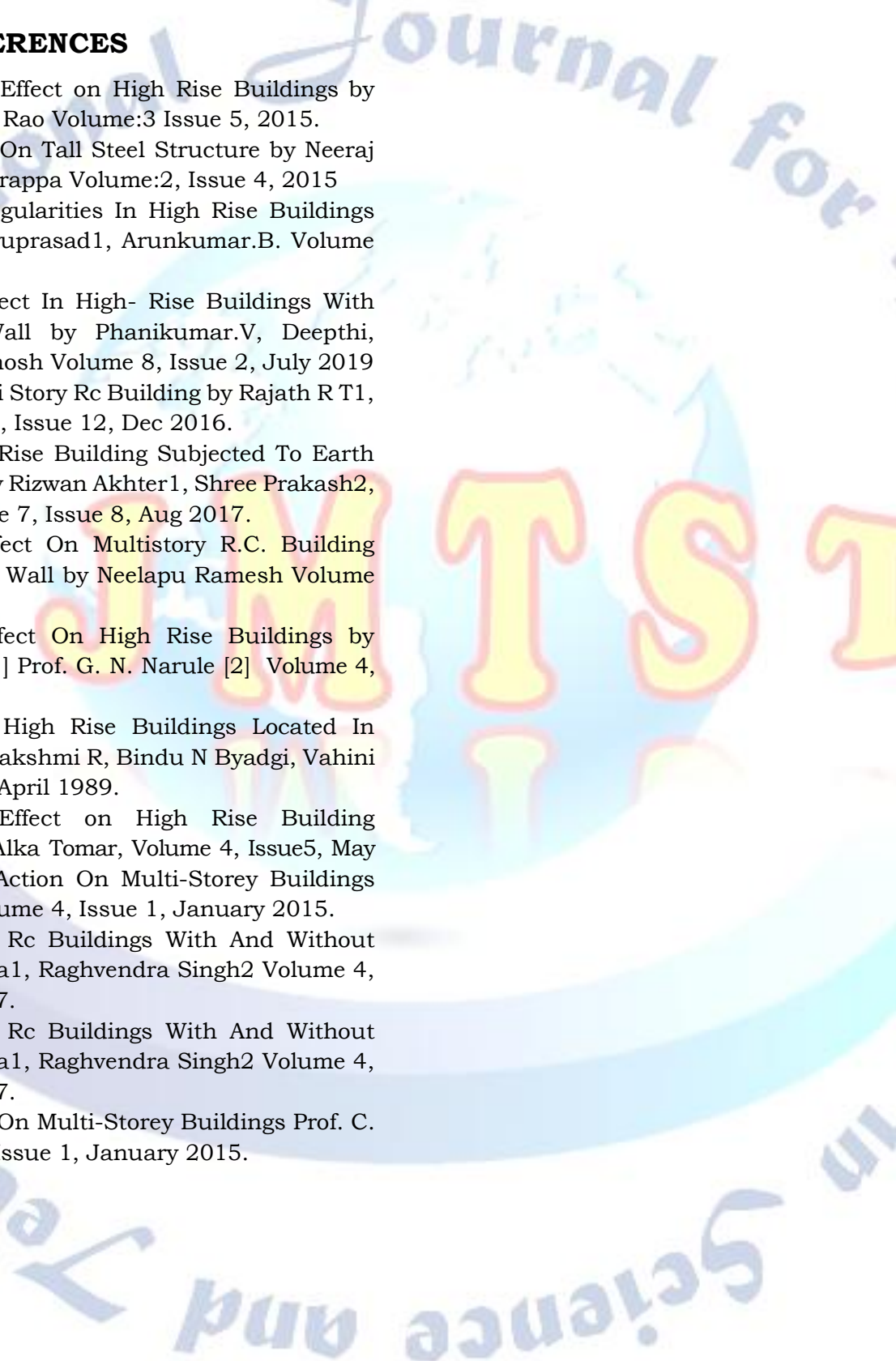